\title{
Role of intestinal metaplasia in the histogenesis of gastric carcinoma
}

\author{
JR JASS \\ From the Department of Histopathology, Westminster Medical School, Horseferry Road, London \\ SWIP $2 A R, U K$
}

SUMMARY Recent evidence suggests that intestinal metaplasia (IM) cannot be regarded as a single entity. A simple classification of IM and its variants based on histological and mucin histochemical criteria was devised, and the incidence of IM subtypes in cancerous and benign gastrectomy specimens was recorded. A particular subtype was associated with 'intestinal' cancers but not with tumours considered to arise in normal gastric epithelium $(P<0.01)$ or with benign lesions $(\mathrm{P}<0.01)$. This subtype appeared to lack absorptive cells at light microscopic level and secreted both neutral and acid mucins, including marked amounts of sulphomucin but no $O$-acetyl sialomucin.

Intestinal metaplasia (IM) is usually a highly differentiated epithelium resembling small intestine as indicated by mucin ${ }^{12}$ and enzyme histochemistry ${ }^{3} 4$ and ultrastructural studies. ${ }^{56}$ Variants of this classical form have been described, and several authors have suggested that these could play a special role in the development of gastric carcinoma..$^{7-11}$ The variants fall into two main groups: an incomplete type shows features of both gastric and small intestinal epithelia, ${ }^{812} 13$ whereas a 'colonic' type has acquired characteristics of large intestine including enzymes $^{14}$ and mucins. ${ }^{9-11}$ The present study was designed to examine further the significance and interrelationships of these variants.

\section{Material and method}

The stomachs examined were resected from patients

Received for publication 24 January 1980 attending Westminster Hospital. They included 48 unselected gastric carcinomas and a selected group of 25 benign specimens (gastric and duodenal ulcers) showing extensive IM.

The specimens were opened and pinned out on to cork mats for preliminary fixation in $10 \%$ buffered formol-saline. After further fixation serial blocks or swiss-rolls were taken along the lesser curvature, greater curvature, anterior wall, and posterior wall. Additional blocks around any lesion were also taken. Six serial sections were cut from each block and stained by haematoxylin and eosin, diastaseperiodic acid Schiff (D-PAS), Alcian blue (AB) pH 2.5/PAS, and high iron diamine/AB. Slides were selected from 16 cases showing extensive IM for staining by the periodate borohydride/ $\mathrm{KOH} / \mathrm{PAS}$ method. Further details of these procedures are given in Table 1.

An attempt was made to classify carcinomas into two groups using the points system outlined in

Table 1 Special methods and their interpretation

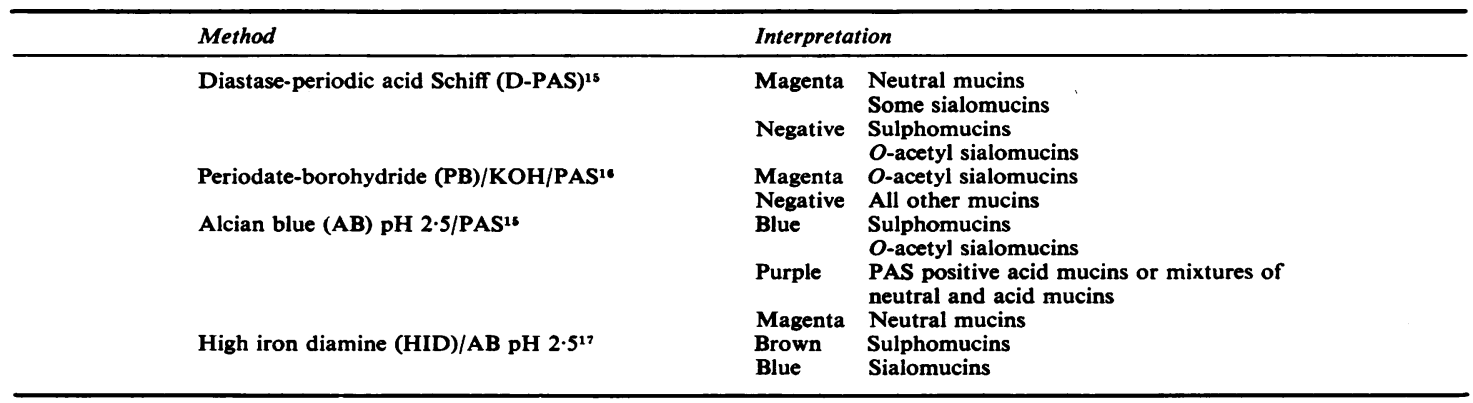


Table 2. Tumours scoring +4 to +8 were regarded as 'intestinal', and those scoring -9 to +3 as 'gastric'. The criteria for this scoring method were derived largely from the observations of Laurén 18 and Ming. ${ }^{19}$

The extent of IM was graded in each section, as shown in Table 3. Both morphological and histochemical criteria were used to classify IM and its variants. Complete IM was characterised by the presence of goblet cells secreting acid mucins and absorptive cells showing a well-developed brush border (Fig. 1). This was designated type I IM. Incomplete IM again comprised goblet cells secreting acid mucins but apparently no mature absorptive cells, their place being taken by columnar mucous cells. When these cells secreted mostly neutral mucins, the epithelium (essentially a simple hybrid of gastric and small intestinal mucous cells) was termed type IIA (Fig. 2). When sulphomucins were abundant in the columnar cells, the variant was designated type IIB (Fig. 3). Cell heights of the IM subtypes were measured in each case. Five readings were taken at the mid portion of a typical crypt and the average height was recorded. In the following the term 'IM' without qualification refers to any type or combination of types.

Table 2 Points system for classifying gastric carcinoma

\begin{tabular}{lr}
\hline Extensive IM around tumour & +3 \\
Little or no IM & -3 \\
Other patterns of IM & 0 \\
Expanding growth & +2 \\
Infiltrating growth & -2 \\
Expanding and infiltrating & 0 \\
Tubular differentiation & +2 \\
Little tubular differentiation & -2 \\
Acid mucins predominate & +1 \\
Absence of mucus secretions & +1 \\
Neutral mucins predominate & -1 \\
Mucins mainly confined to signet ring cells & -1 \\
\hline & \\
+4 to +8 'intestinal'. & \\
-9 to +3 'gastric'. & $(<5 \%)$ \\
Table 3 Grading of intestinal metaplasia & \\
\hline Little or none & $(20-100 \%)$ \\
Moderate & \\
Extensive & +10 \\
\hline
\end{tabular}

\section{Results}

Using the points system indicated in Table 2, it was possible to divide the 48 carcinomas into 23 'intestinal' and 25 'gastric' types. This was an attempt at a histogenetic classification, the terms 'intestinal' and 'gastric' implying the likely precursor epithelium. All 23 'intestinal' cancers were associated with extensive IM, but this was found in only seven of the 'gastric' cases.

Complete or type I IM (Fig. 1) usually resembled small intestine though villi were rarely well developed and the ratio of goblet cells to absorptive cells was variable. Sometimes goblet cells were numerous in the lower half of crypts, conferring a likeness to colonic mucosa. However, the mucin histochemistry mostly resembled small intestine with $N$-acetyl sialomucins predominating. In the majority of cases the occasional crypt contained a mixed population of goblet cells, some secreting $O$ - and some $N$-acetyl sialomucins (Table 4). In one case (an 'intestinal' cancer scoring +4$)$, the secretion of $O$-acylated sialomucins was marked (Fig. 4). Sulphomucins were detected only patchily in type I IM.

Type IIA IM (Fig. 2) comprised intestinal goblet cells and columnar shaped mucous cells. The goblet cells secreted $\mathrm{N}$-acetyl sialomucins and occasionally a sulphomucin, but, unlike type I, no $O$-acetyl sialomucins (Table 4). The bordering columnar cells secreted mainly neutral mucins. The secretory material was either limited to the cell apex or occupied the whole cell. Sometimes small amounts of $N$-acetyl sialomucin were also present, but sulphomucins were encountered as a trace if at all. Cells at the base of the crypts secreted droplets of sulphomucin at times but appeared to lose this capacity as they matured. Paneth cells were rarely observed.

Type IIB IM resembled IIA in showing incomplete differentiation. Thus goblet cells were again bordered by columnar mucous cells instead of absorptive cells. However, the columnar cells secreted marked amounts of sulphomucin. These cells were often distended with mucus and only with special stains distinguished easily from adjacent intestinal goblet cells which usually produced a sialomucin (Fig. 3). With haematoxylin and eosin this epithelium frequently resembled hyperplastic colonic mucosa. This feature, together with the sulphomucin secretion and rarely observed Paneth cells, invited the term 'colonic metaplasia'. However, unlike normal colonic mucosa, there was no secretion of $O$-acylated sialomucin (Table 4) (Fig. 5). The mucin histochemistry of IM and its variants is summarised in Figure 6. There were also structural features distinguishing types IIA and IIB IM. The overall architecture of IIB mucosa tended to be more irregular. The crypts were elongated, tortuous, and branched, and papillary formations were numerous. The cells lining IIB crypts were taller than those of IIA (see below).

Increased sulphomucin secretion was noted in other sites. Branched glands lined by a low columnar epithelium and arising at the base of intestinalised 


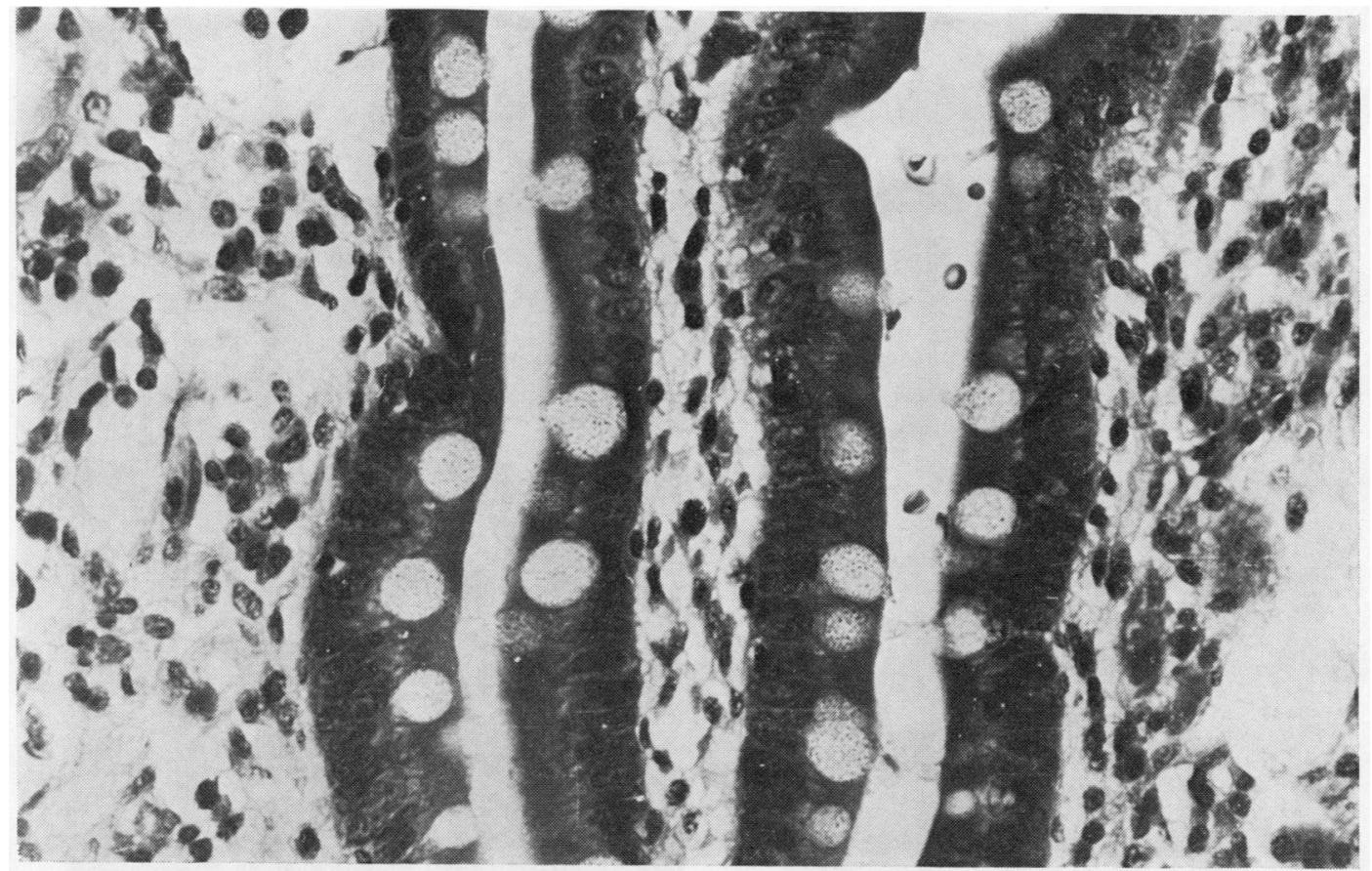

(a)

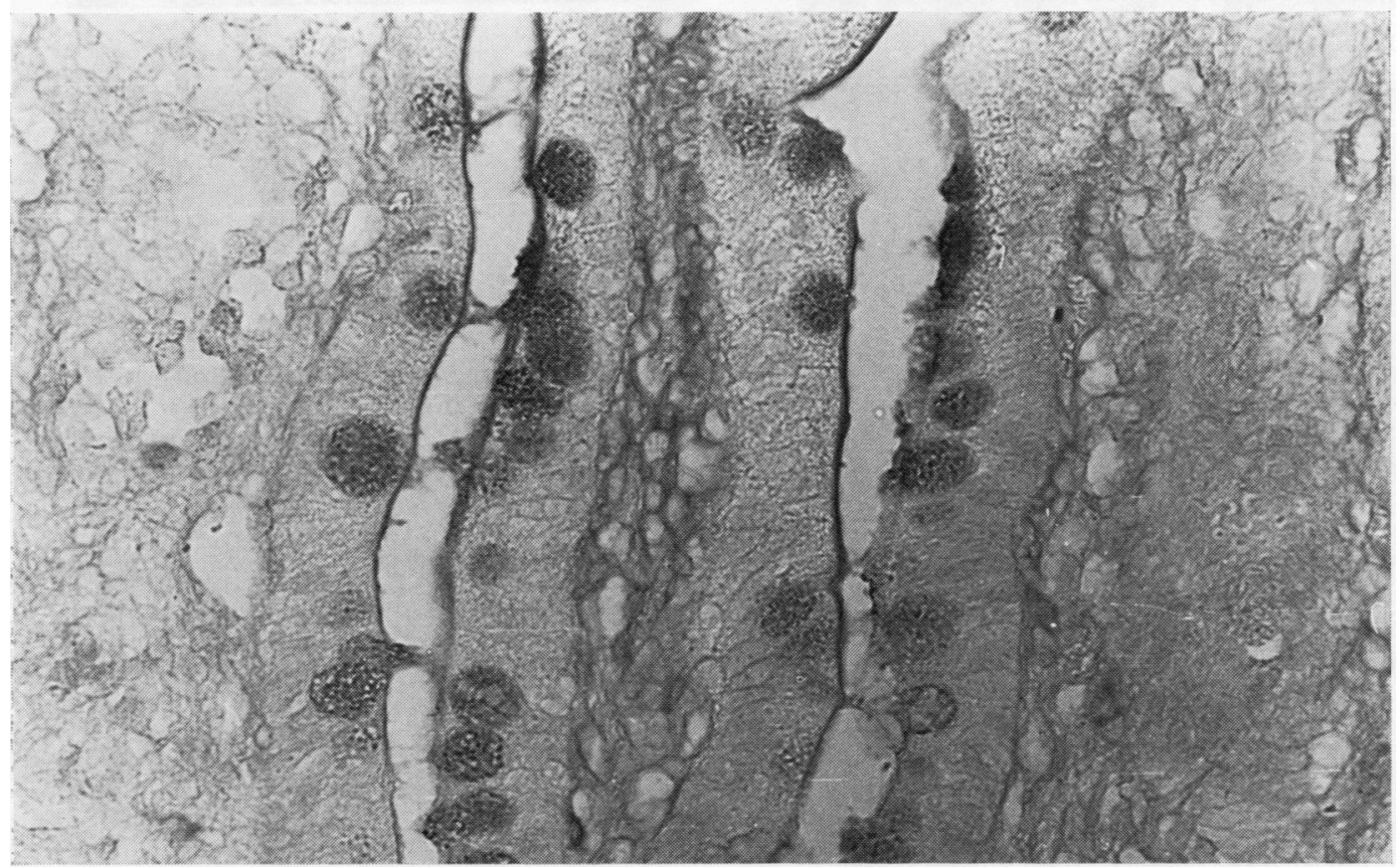

(b)

Fig. 1 (a) $H$ and E. (b) HID/AB. Complete or type I intestinal metaplasia. The crypts are lined by absorptive cells and goblet cells. The latter secrete sialomucins only. A well-developed brush border is shown $(\times 450)$. 


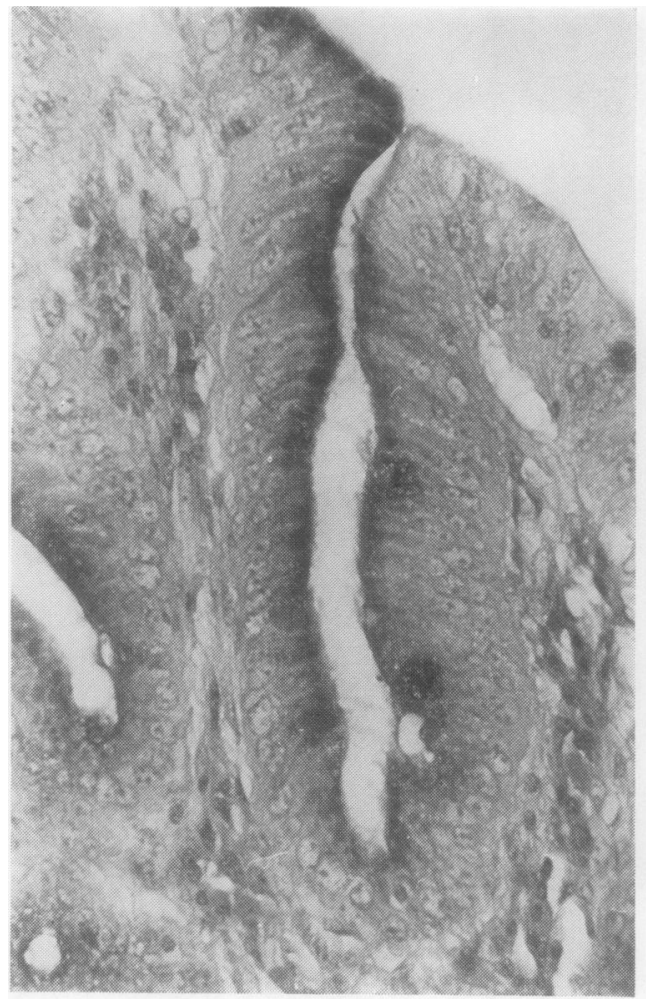

(a)

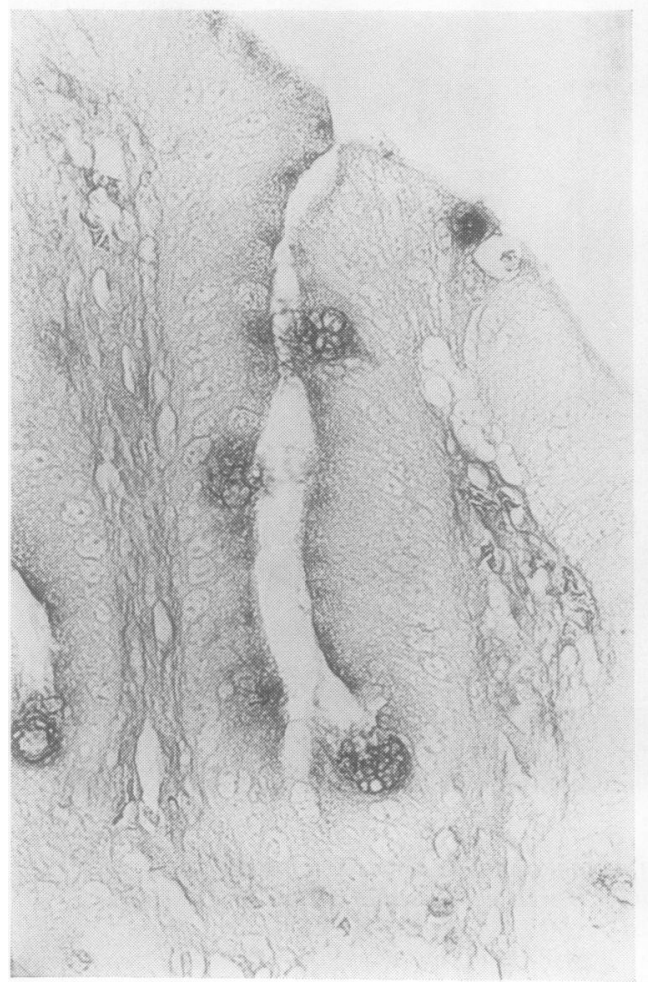

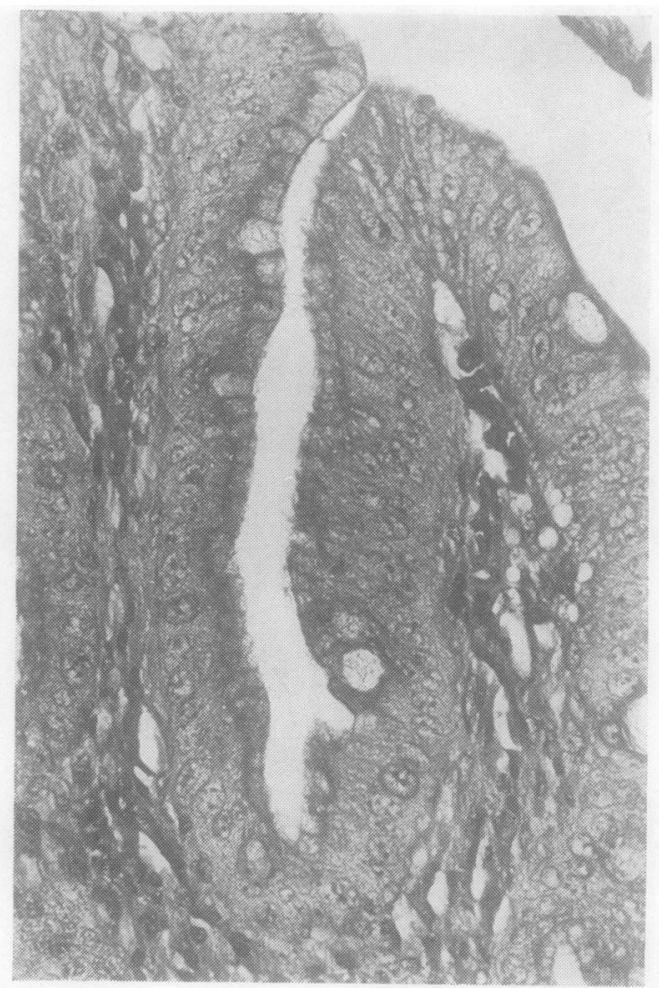

(b)

Fig. 2 (a) $P A S$. (b) $H$ and E. (c) $H I D / A B$. Type $I I A$ intestinal metaplasia. The cells lining the crypt are taller than those of type I IM and comprise goblet cells secreting sialomucins and columnar shaped mucous cells secreting mostly neutral mucins. There is no welldeveloped brush border $(\times 450)$. 


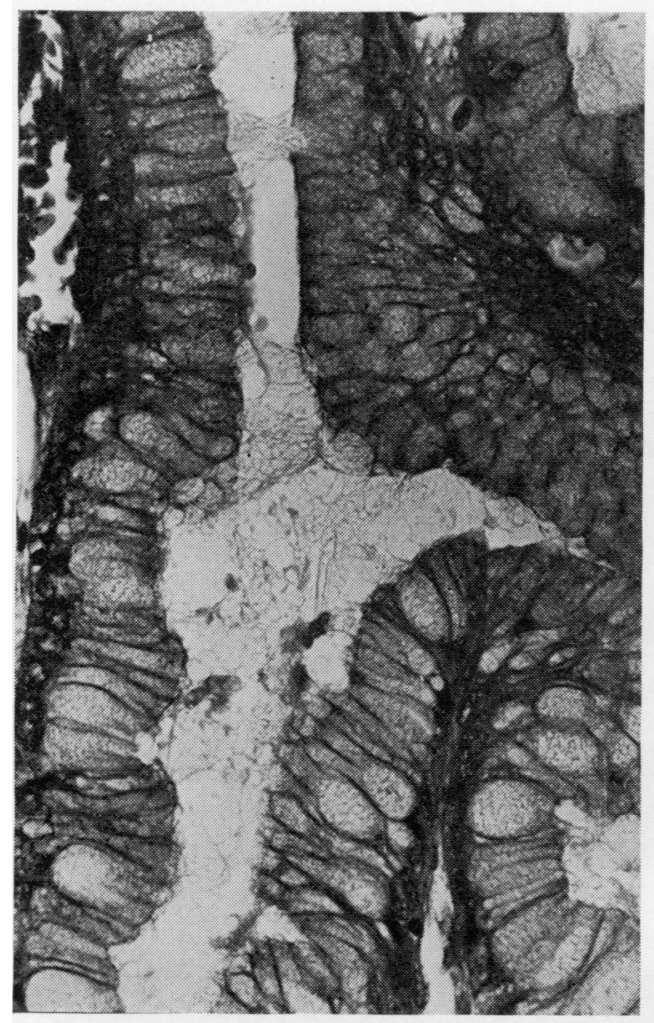

(a)

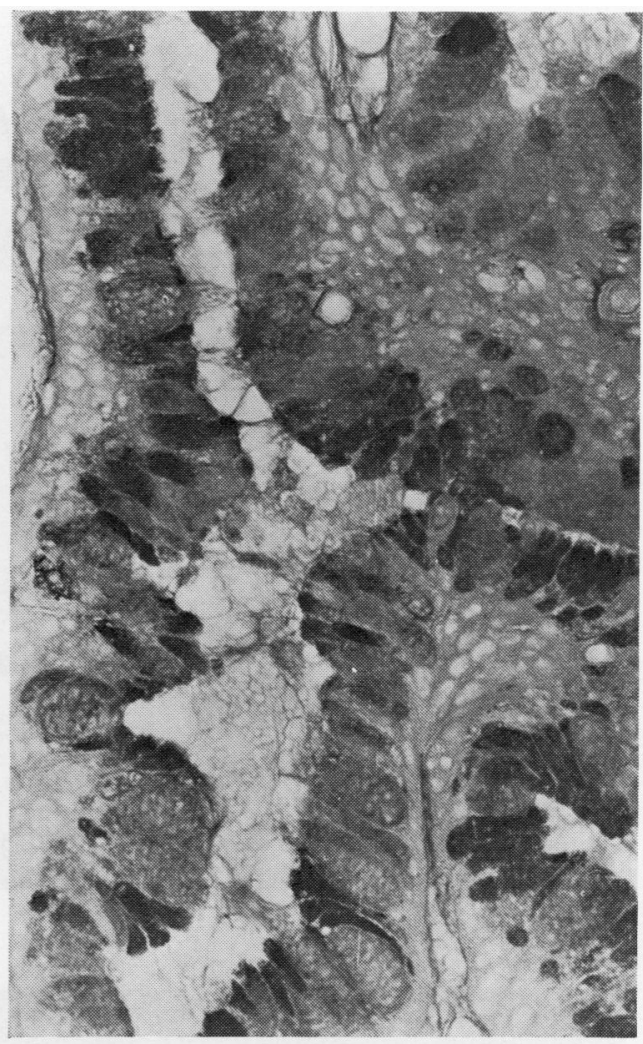

(b)

Fig. 3 (a) $H$ and $E$. (b) HID/AB. Type IIB intestinal metaplasia. The presence of two types of mucous cell is not obvious with $H$ and $E$. With $H I D / A B$ the larger goblet cells secrete sialomucins and the intervening less distended cells secrete sulphomucins. There is no well-developed brush border $(\times 450)$.

Table 4 Incidence of $P B / K O H / P A S$ positive staining in variants of IM

\begin{tabular}{lll}
\hline IM type & $\begin{array}{l}\text { Incidence of type in 16 cases } \\
\text { showing extensive IM }\end{array}$ & $\begin{array}{l}\text { PB/KOH/PAS positive } \\
\text { goblet cells }\end{array}$ \\
\hline I & 14 & 12 \\
IIA & 4 & 0 \\
IIB & 4 & 0 \\
\hline
\end{tabular}

crypts (IIA or IIB usually) sometimes secreted sulphated material. Sulphomucins (and sialomucins) were also seen in sites not showing obvious IM as judged histologically, such as in dilated acini or in the lower half of antral crypts (possibly representing incipient IM). Very occasionally apparently normal surface epithelium bordering gastric cancer showed sulphomucin secretion. Finally, sulphomucins were frequently observed in dysplastic and carcinomatous epithelia. In cancers this was usually encountered as an extracellular secretion, either glycocalyceal, intraluminal, or in pools. $O$-acylated sialomucins were not observed in any of these sites.

The cells comprising type IIB IM were taller than those of type IIA, which were in turn taller than those of type I. The mean cell heights of IIB, IIA, and I were $39 \mu \mathrm{m}, 30 \mu \mathrm{m}$, and $23 \mu \mathrm{m}$. The difference between the mean cell height of type IIB and type IIA was significant, as was the difference between IIA and $\mathrm{I}(\mathrm{P}<0.02$ and $<0.001$, respectively). Cell height was also more variable in IIB than in IIA or I, as indicated by the respective standard deviations (13 $\mu \mathrm{m}, 7 \mu \mathrm{m}$, and $4 \mu \mathrm{m})$. The incidence of IM and its variants in specimens showing extensive IM is given in Table 5. Type I IM was found in the majority of cases, but two cancers showed IIB only and two gastric ulcers IIA only. The association of type IIB IM with 'intestinal' cancers appeared to be significant when compared with either 'gastric' cancers $(P<0.01)$ or benign specimens $(P<0.01)$. Moreover, type IIB IM was always most marked in the epithelium immediately bordering cancers. None of 


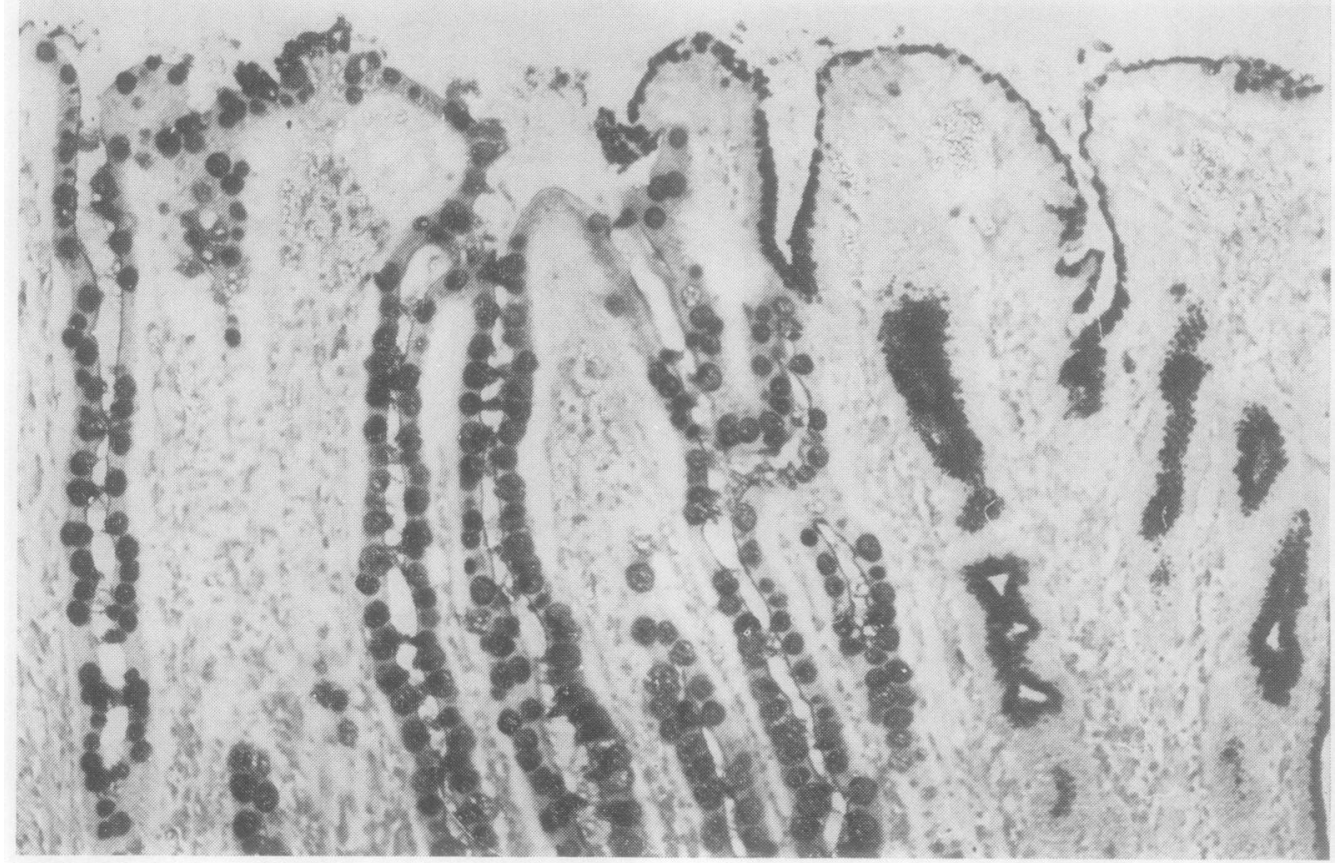

(a)

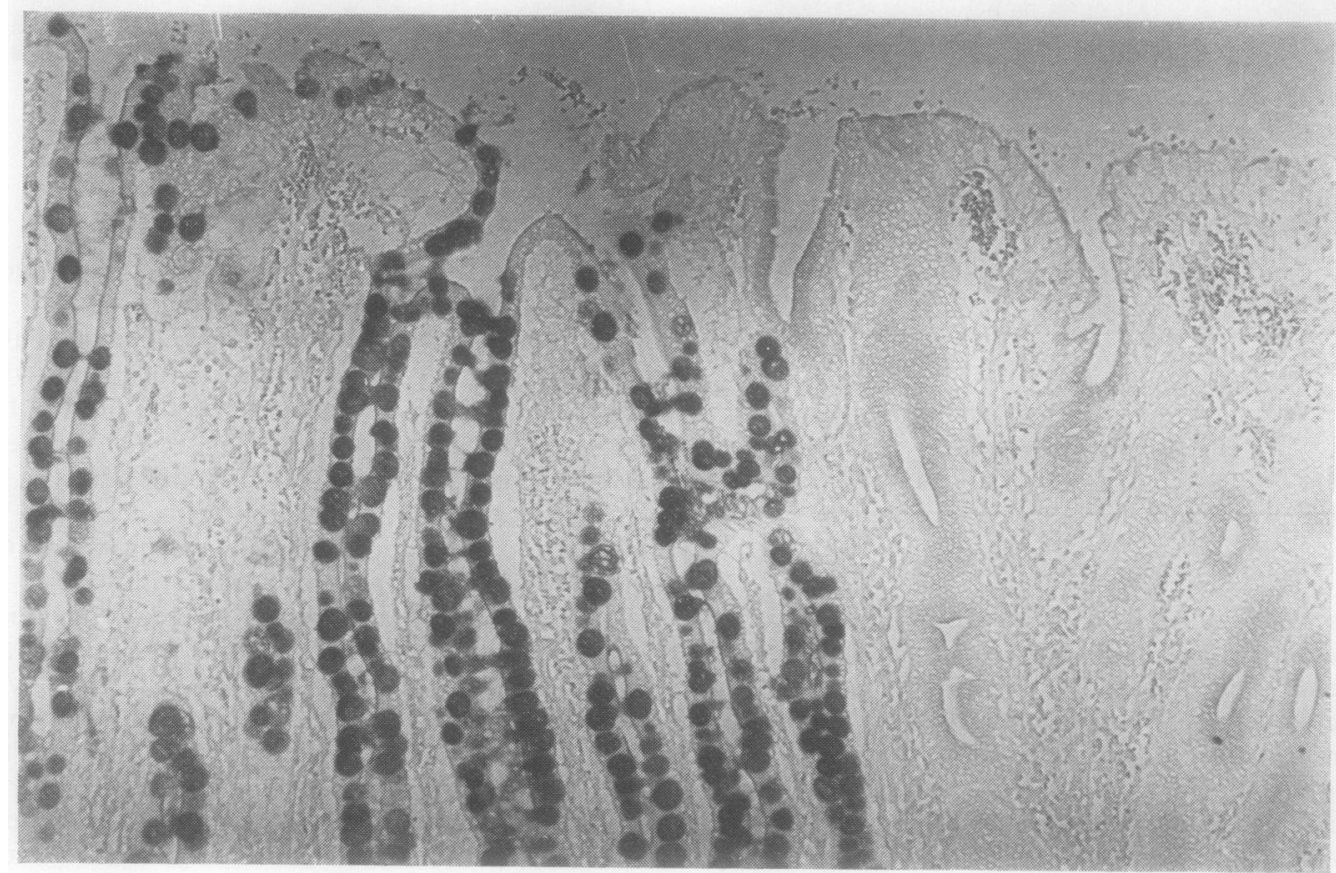

(b)

Fig. 4 (a) PAS. (b) PB/KOH/PAS. Type I intestinal metaplasia (left) and normal gastric mucosa (right). The goblet cells are more numerous than the example shown in Fig. 1, but absorptive cells with a well-developed brush border are present. Only the goblet cells are stained by the PB/KOH/PAS method, indicating secretion of O-acylated sialomucins $(\times 115)$. 


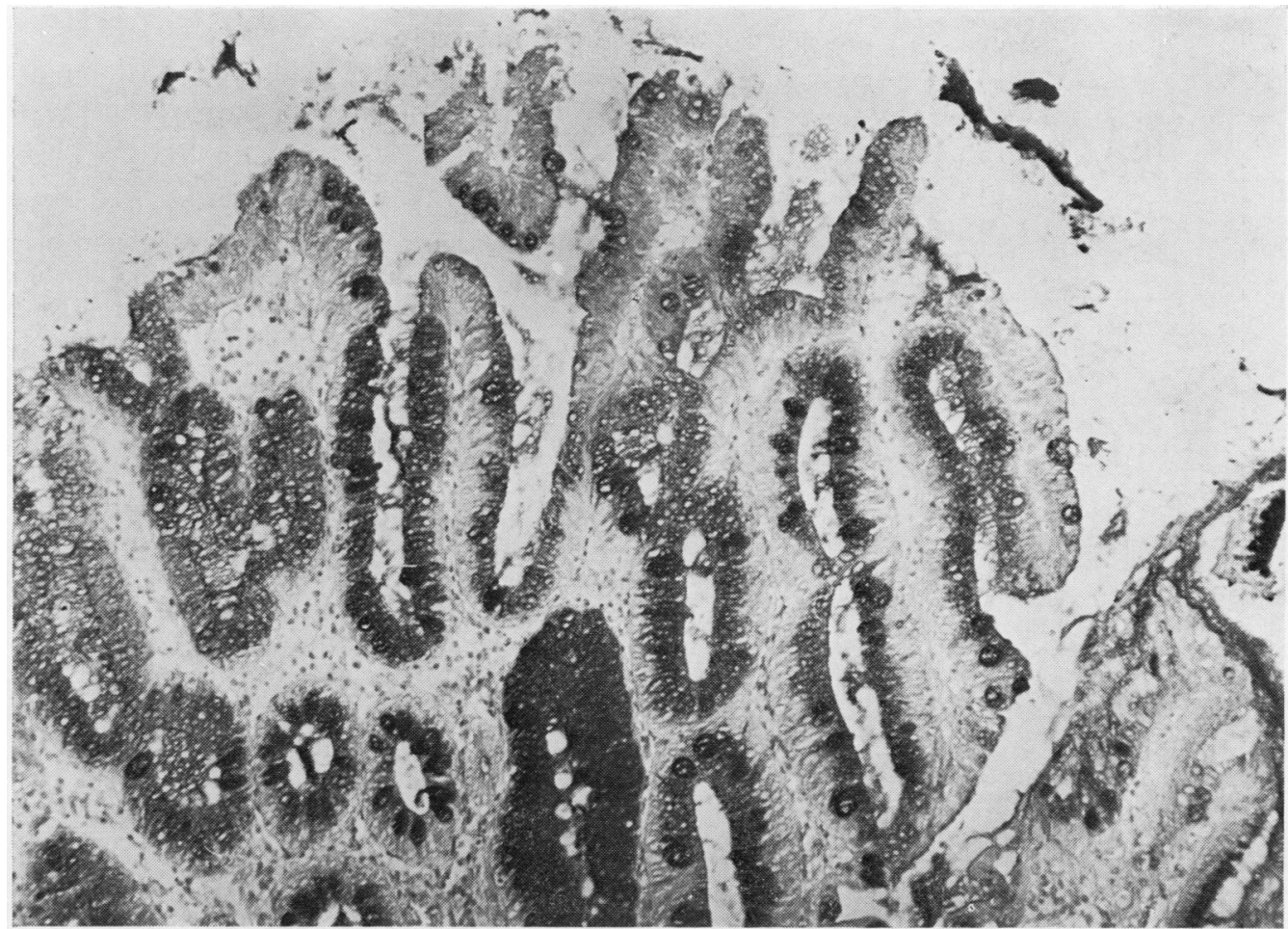

(a)

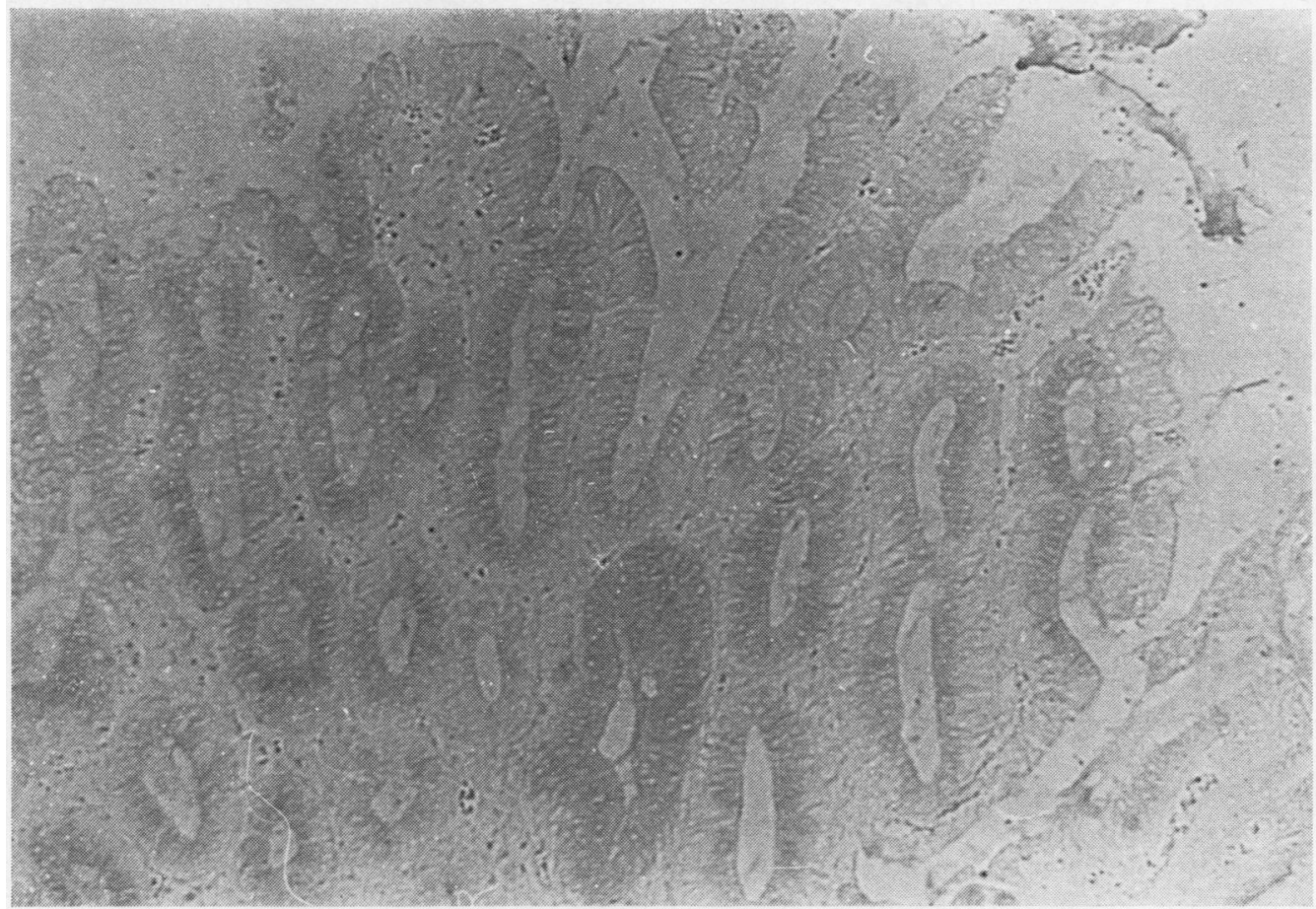

(b)

Fig. 5 (a) PAS. (b) $P B / K O H / P A S$. Type IIB intestinal metaplasia. There is no secretion of O-acylated sialomucins $(\times 115)$. 
TYPE I
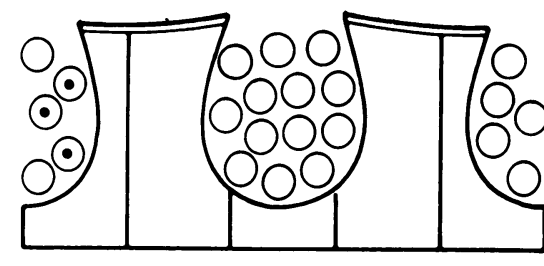

TYPE IIa

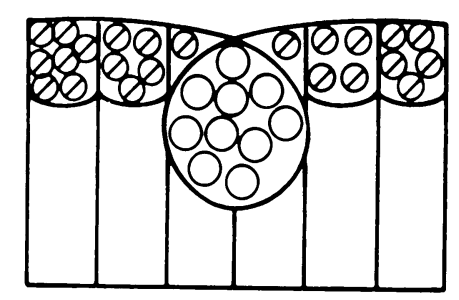

TYPE IIb

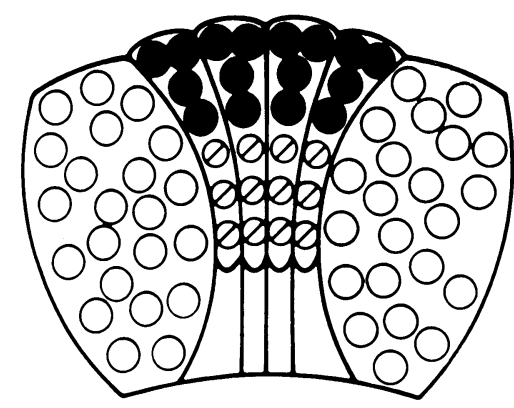

Fig. 6 Diagram summarising the mucin histochemistry of intestinal metaplasia and its variants. $\oslash$ neutral mucins; $\bigcirc$ sialomucins; $\bigcirc$ O-acetyl sialomucins; - sulphomucins.

Table 5 Incidence of IM subtypes in cases showing extensive IM

\begin{tabular}{llll}
\hline IM type & $\begin{array}{l}\text { 'Intestinal' } \\
\text { cancers }\end{array}$ & $\begin{array}{l}\text { 'Gastric' } \\
\text { cancers }\end{array}$ & $\begin{array}{l}\text { Benign } \\
\text { lesions }\end{array}$ \\
\hline Extensive & 23 & 7 & 25 \\
I & 21 & 7 & 23 \\
IIA & 6 & 1 & 13 \\
IIB & 17 & 0 & 2 \\
\hline
\end{tabular}

the other variants showed any significant association with the cancerous specimens. The high incidence of type IIA IM in benign cases appeared significant when compared to the incidence in malignant cases taken as a whole $(\mathrm{P}<0.05)$. The association of
$O$-acylated sialomucins with type I IM but not with IIA and IIB also appeared to be significant $(\mathrm{P}<0.01)$.

\section{Discussion}

Morphological, ${ }^{20} 21$ epidemiological, ${ }^{22}$ and prospective studies ${ }^{2324}$ suggest that intestinal metaplasia (IM) may be a premalignant lesion. It is generally accepted that only a proportion of gastric cancers arise from IM. These apparently form a welldefined group showing tubular differentiation and an expanding as opposed to a diffuse pattern of growth.181925 However, several authors have pointed out that 'intestinal' differentiation in a tumour need not always indicate an origin from an intestinalised mucosa. ${ }^{34132627}$ An attempt at a histogenetic classification was made in the present study in which importance was attached to the presence of IM around tumours (Table 2). Thus carcinomas showing 'intestinal' differentiation but little or no IM in the adjoining mucosa were not included in the 'intestinal' group.

While it is acknowledged that some gastric cancers may arise from IM, there are certain objections to calling IM premalignant. Firstly, it is a highly differentiated mucosa resembling small intestine morphologically ${ }^{6}$ and histochemically. ${ }^{1-4}$ Secondly, it is an extremely common finding. ${ }^{20}{ }^{28}$ An answer to both these objections may be provided by the recent demonstration of incomplete variants of IM. In these, absorptive cells either show incomplete differentiation $^{813}$ or are apparently absent at light microscopic level, their place being taken by simple mucous cells. ${ }^{81013}$ Small intestinal enzymes, such as alkaline phosphatase and aminopeptidase (normally present along the brush border of absorptive cells), are reduced in amount or absent. ${ }^{11429}$ In addition to these negative findings, some variants appear to have acquired colonic characteristics, including enzymes ${ }^{14}$ and mucins. ${ }^{9-11}$ Several authors have indicated that IM variants could play a special role in the histogenesis of gastric cancer. ${ }^{7-1130}$

Complete or type I IM was not entirely uniform in its differentiation since 'colonic' mucins, including sulphomucins and $O$-acetyl sialomucins, ${ }^{31}$ were frequently demonstrated, though in small amounts. In one case, however, $O$-acetyl sialomucin was marked (Fig. 4). This variant of type I IM is probably synonymous with one description of 'colonic' metaplasia occurring as scattered foci in cases of 'intestinal' cancer. ${ }^{9}$ While such anomalous differentiation may be associated with 'intestinal' cancers, the results of the present study do not support a direct histogenetic link between this variant and cancer. Type IIA IM, a simple hybrid of gastric and small intestinal epithelia, is syn- 
onymous with the well-documented partial or incomplete IM. ${ }^{6} 813$ There was no association between this type and cancer. Type IIB is probably at least in part synonymous with 'enterocolic' metaplasia ${ }^{11}$ and was associated with 'intestinal' cancers but not with 'gastric' cancers or benign specimens showing extensive IM.

It is not certain whether enzyme studies can differentiate between types IIA and IIB. Absorptive cells may be present in IIA but show incomplete differentiation with only a partially developed brush border. ${ }^{813}$ Intestinal enzymes may then be present, though perhaps reduced in amount. An incomplete variant lacking small intestinal enzymes but producing cytoplasmic 'colonic' enzymes has been described. ${ }^{14}$ It remains to be shown whether this is synonymous with type IIB IM.

Apart from its association with gastric cancer, what evidence is there to suggest that type IIB IM may be premalignant? It is unlikely to be a secondary reactive phenomenon to tumour growth because of its association with 'intestinal' cancers but not 'gastric' cancers. Furthermore, gastric adenomatous polyps and dysplastic change appear to arise in type IIB IM. ${ }^{30}$ Also of relevance is a striking histological and histochemical similarity between type IIB IM and the columnar epithelium of Barrett's oesophagus.32 On the other hand, while type IIB IM may be described as hyperplastic (being composed of crowded elongated cells) and showing incomplete differentiation, it is not obviously dysplastic. Interestingly, hyperplasia has been described as an early change in various sites of experimental carcinogenesis, such as colon $^{33}$ and small intestine ${ }^{34} \mathbf{3 5}^{35}$ as well as stomach..$^{36}{ }^{37}$ Moreover, in the rat stomach, hyperplasia is accompanied by altered patterns of mucin secretion, with increased production of acid mucins including sulphomucins. ${ }^{37}$ Also of relevance is the description of tumour antigens in 'normal' mucosa bordering gastric cancer. These include alpha fetoprotein, ${ }^{38}$ carcinoembryonic antigen, ${ }^{39} 40$ and goblet cell antigen ${ }^{41}$ all found within IM. It is not clear whether a fourth tumour marker, termed fetal sulphoglycoprotein antigen, also occurs in a metaplastic epithelium. ${ }^{42}$ However, it has been suggested that this could be related to the sulphomucin of type IIB IM. ${ }^{30}$ Thus there are grounds for regarding type IIB IM as a premalignant change, and a prospective study is now in progress to confirm or refute this.

This work was supported by a grant from the Westminster Joint Research Committee. I thank Dr MI Filipe for her help and guidance, the laboratory staff for preparing the numerous sections, and Mrs A Leaver for typing the manuscript.

\section{References}

${ }^{1}$ Lev R. The mucin histochemistry of normal and neoplastic gastric mucosa. Lab Invest 1966;14:2080-100.

${ }^{2}$ Goldman H, Ming SC. Mucins in normal and neoplastic gastrointestinal epithelium. Arch Path 1968;85:580-6.

${ }^{3}$ Wattenberg LW. Histochemical study of aminopeptidase in metaplasia and carcinoma of the stomach. Arch Path 1959;67:281-6.

${ }^{4}$ Planteydt HT, Willighagen RGJ. Enzyme histochemistry of the human stomach with special reference to intestinal metaplasia. J Path Bact 1960;80:317-22.

${ }^{5}$ Rubin W, Ross RH, Jeffries GH, Sleisinger MH. Intestinal heterotopia-a fine structural study. Lab Invest 1966; 15:1024-49.

${ }^{6}$ Goldman H, Ming SC. Fine structure of intestinal metaplasia and adenocarcinoma of the human stomach. Lab Invest 1968;18:203-10.

7 Johansen AA. Early gastric cancer. In: Morson BC, ed. Current Topics in Pathology vol 63. Berlin, Heidelberg: Springer-Verlag, 1976;1-47.

${ }^{8}$ Iida F, Murata F, Nagata T. Histochemical studies of mucosubstances in metaplastic epithelium of the stomach with special reference to the development of intestinal metaplasia. Histochemistry 1978;56:229-37.

'Teglbjaerg PS, Nielsen HO. 'Small intestinal type' and 'colonic type' intestinal metaplasia of the human stomach. Acta Pathol Microbiol Scand 1978;86:351-5.

${ }^{10}$ Jass JR, Filipe MI. A variant of intestinal metaplasia associated with gastric carcinoma: a histochemical study. Histopathology 1979;3:191-9.

${ }^{11}$ Heilmann KL, Höpker WW. Loss of differentiation in intestinal metaplasia in cancerous stomachs. A comparative morphologic study. Path Res Pract 1979; 164:249-58.

12 Tarpila S, Telkkä A, Siurala M. Ultrastructure of various metaplasias of the stomach. Acta Path Microbiol Scand 1969;77:187-95.

${ }^{13}$ Ming SC, Goldman H, Freiman DG. Intestinal metaplasia and histogenesis of carcinoma of the human stomach. Cancer 1967;20:1418-29.

${ }^{14}$ Abe M, Ohuchi N, Sakano H. Enzyme histo- and biochemistry of intestinalized gastric mucosa. Acta Histochem Cytochem 1974;7:282-7.

${ }^{15}$ Pearse AGE. Histochemistry Theoretical and Applied. 3rd ed. London: Churchill, 1968.

${ }^{16}$ Culling CFA, Reid PE, Clay MG, Dunn WL. The histochemical demonstration of $\mathrm{O}$-acylated sialic acid in gastrointestinal mucins: their association with the potassium hydroxide-periodic acid-Schiff effect. $J$ Histochem Cytochem 1974;22:826-31.

${ }^{17}$ Spicer SS. Diamine methods for differentiating mucosubstances histochemically. J Histochem Cytochem 1965; 13:211-34.

${ }^{18}$ Laurén $P$. The two main histological types of gastric carcinoma; diffuse and so-called intestinal type carcinoma. An attempt at a histo-clinical classification. Acta Path Microbiol Scand 1965;64:31-49.

19 Ming SC. Gastric carcinoma: a pathobiological classification. Cancer 1977;39:2475-85.

${ }^{20}$ Morson BC. Intestinal metaplasia of the gastric mucosa. Brit J Cancer 1955;9:365-76.

${ }^{21}$ Morson BC. Carcinoma arising from areas of intestinal metaplasia in the gastric mucosa. Brit J Cancer 1955; 9:377-85.

${ }^{22}$ Imai $T$, Kubo $T$, Watanabe $H$. Chronic gastritis in Japanese with reference to the high incidence of gastric carcinoma. J Natl Cancer Inst 1971;47:179-95.

${ }^{23}$ Walker IR, Strickland IG, Ungar B, Mackay IR. Simple atrophic gastritis and gastric carcinoma. Gut 1971; 
$12: 906-11$

${ }^{24}$ Siurala M, Seppälä K. Atrophic gastritis as a possible precursor of gastric carcinoma and pernicious anaemia. Acta Med Scand 1960;166:445-74.

${ }^{25}$ Nakamura K, Sugano H, Takagi K. Carcinoma of the stomach in incipient phase; its histogenesis and histological appearances. Gann 1968;59:251-8.

${ }^{26}$ Stemmerman GN. Comparative study of histochemical patterns in non-neoplastic and neoplastic gastric epithelium. A study of Japanese in Hawaii. J Natl Cancer Inst 1967;39:375-83.

${ }^{27}$ Kobori O, Oota K. Mucous substance and enzyme histochemistry of non-neoplastic and neoplastic gastric epithelium in man. Acta Path Jap 1974;24:119-30.

${ }^{28}$ Skinner JM, Heenan PJ, Whitehead R. Atrophic gastritis in gastrectomy specimens. Brit J Surg 1975;62:23-5.

${ }^{29}$ Kawachi T, Kurisu M, Numanyu N, Sasajima K, Sano T, Sugimura T. Precancerous changes in the stomach. Cancer Res 1976;36:2673-7.

30 Jass JR. Filipe MI. Sulphomucins and precancerous lesions of the human stomach. Histopathology (in press).

${ }^{31}$ Filipe MI. Mucins in the human gastrointestinal epithelium: a review. Invest Cell Pathol 1979;2:195-216.

${ }^{32}$ Ozzello L, Savary M. Roethlisberger B. Columnar mucosa of the distal oesophagus in patients with gastrooestopageal reflux. In: Sommers SC, Rosen PR, eds. Pathology Annual vol 12. New York: Appleton-Century-Crofts, 41-86.

${ }^{33}$ Thurnherr N, Deschner EE, Stonehill EH, Lipkin $M$. Induction of adenocarcinomas of the colon in mice by weekly injection of 1.2 dimethylhydrazine. Cancer Res 1973;33:940-5.

${ }^{34}$ Wiebecke B, Krey U, Lohrs U, Eder M. Morphological and autoradiographical investigations in experimental carcinogenesis and polyp development in the intestinal tracts of rats and mice. Virchows Arch (Pathol Anat) $1973 ; 360: 179-93$.
3.5 Filipe MI. Mucus secretion in rat colonic mucosa during carcinogenesis induced by dimethylhydrazine. A morphological and histochemical study. Brit $J$ Cancer 1975;32:60-77.

${ }^{36}$ Schlake W, Nomura K. Histogenesis of carcinoma in the glandular stomach of the rat after Billroth I resection. In: Grundmann E, ed. Topics in Pathology vol 67. Berlin, Heidelberg: Springer-Verlag, 1979;1-68.

${ }^{37}$ Tsiftsis D, Jass JR, Filipe MI. Wastell C. Altered patterns of mucin secretion in precancerous lesions induced in the glandular part of the rat stomach by the carcinogen $\mathrm{N}$-methyl- $\mathrm{N}^{\prime}$-nitro-N-nitrosoguanidine (in preparation).

${ }^{38}$ Kitaoka H, Hattori N, Mucojima T, Ohkura H, Nakayama $\mathrm{N}$, Okada $\mathrm{H}$. Alpha-fetoprotein content in tissues from patients with gastric cancer. Tumour Res 1973;8:171-7.

${ }^{39}$ Burtin $\mathrm{P}$, von Kleist S, Sabine MC, King M. Immunohistological localization of carcinoembryonic antigen and non-specific cross-reacting antigen in gastrointestinal normal and tumoral tissue. Cancer Re's 1973;33:3299305 .

" Mori T, Wakumoto H, Shimano T, Lee PK. Higashi H. Immunopathological studies on CEA and CEAassociated antigens with revaluation of the cancer specificities of CEA. Ann NY Acad Sci 1975;259:412-6.

$"$ Rapp W, Windisch M, Peschke P, Wurster K. Purification of human intestinal goblet cell antigen. Its immunohistological demonstration in the intestine and in mucus producing adenocarcinomas. Virchow's Arch (Pathol Anat) $1979 ; 382: 163-77$.

${ }^{12}$ Häkkinen I, Järvi O. Grönroos J. Sulphoglycoprotein antigens in the human alimentary canal and gastric cancer. An immunohistological study. Int $J$ Cancer $1968 ; 3: 572-81$

Requests for reprints to: Dr JR Jass, Department of Histopathology, Westminster Medical School, Horseferry Road, London SW1P 2AR, UK. 